\title{
Unpublished Demotic Ostracon from Medinet Habu Dealing with Poll Tax
}

The text published in this study is a part of a collection of Demotic ostraca in the Cairo-Museum which were originally collected by the Oriental Institute during their 1929/30 season of excavation at Medinet $\mathrm{Habu}^{(1)}$. One hundred and sixty texts were chosen and published by Lichtheim ${ }^{(2)}$ in 1955 . The remaining ostraca were returned to the Cairo Museum and bear the inventory number $189522^{\frac{25}{55} / \frac{1}{3}}$ and kept on the third floor (23 east). In 2005 Wahid El-Din published forty-two of them ${ }^{(3)}$.

The present study contains one text concerning poll tax. It is Roman in date and referred to 26 Tybi of year 24 of Augustus which equals 21 January 6 B.C ${ }^{(4)}$.

The poll tax was one of the most important sources of income in the Roman period $^{(5)}$, and was called $\lambda \alpha o \gamma \rho \alpha \phi i \alpha$. It was related to the census which was performed every 14 years $^{(6)}$.

Every Egyptian male from the age of 14 to 60 had to pay this tax except for the Roman citizens and some privileged persons who were exempted.

The rate of this tax varied in the different towns and "even within the limits of the Theban nome"(7).

Wallace suggested that there were two rates for the tax in Thebes, the first was 2 staters and 1 kite (=10 drachmas), and the second was 6 staters $(=24 \text { drachmas })^{(8)}$, while Mattha suggested that the first rate was 4 staters (=16 drachmas) and the second was 2 staters and 1 kite $(=10 \text { drachmas })^{(9)}$.

I prefer the suggestion of Mattha because most of the rates of the poll tax in the published demotic texts from Thebes are between 4 staters (=16 drachmas) and 2 staters and 1 kite (=10 drachmas) and the rate of 6 staters ( 24 drachmas) is not shown in any demotic receipts until now.

(1) Mrdinet Habu located at the western bank of the Nile at Thebes.

(2) Lichtheim, M., Demotic Ostraca from Medinet Habu, New Haven, 1955.

(3) Wahid El-Din, S., Demotic Ostraca from Thebes in the Egyptian Museum, 2 parts, Thesis to obtain the Ph.D. Degree in Ancient Egyptian Language, Under the Supervision of Prof. Dr. M. A. A. Nur ElDin and Prof. Dr. M. A. Abd El-Monaem, Department of Egyptian Civilizations, Institute of Ancient Near Eastern Studies, Zagazig University, 2005.

(4) Pestman, P. W., Chronologie Égyptienne d' après les Textes Démotiques (332 aV. J.-C. 453 ap. J.c.), Leiden, 1967 (papyrological Lugduno-Batava 15).

(5) Nur El-Din, M. A. A., Demotic Ostraca from the National museum at Leiden, Leiden, 1974, p. 12.

(6) Wallace, S. L., Taxation in Egypt from Augustus to Diocletion, Princeton and London, 1938 (Princeton University Studies in Papyrology 2), p. 116.

(7) Lichtheim, op. cit., p. 16.

(8) Wallace, op. cit., p. 131; Vleeming, S. P., Ostraka Varia, Tax Receipts and Legal Documents on Demotic, Greek, and Greek-Demotic Ostraka, Chiefly of the Early Ptolemaic Period, From Various Collectoins, E. J. Brill, Leiden, New York and Köln, 1994 (Papyrologica Lugduno-Batava 26)., nr. 58, n. dd.

(9) Sometimes this rate was written as 21/2 staters, see: Mattha, G., Demotic Ostraka from the Collections at Oxford, Paris, Berlin, Vienna and Cairo, Le Caire, 1945, p. 45. 
Unpublished Demotic Ostracon from Medinet Habu Dealing with Poll Tax

The rate of 4 staters ( $=16$ drachmas) is paid in installments or in bulk, while the rate of 2 staters and 1 kite (=10 drachmas) is paid only in bulk ${ }^{(10)}$.

"The poll-tax was but one of the taxes which had caused a large part of the populace to flee from their homes and abandon the cultivation of the soil." ${ }^{(11)}$.

As for dating of the present text, I depend on the internal evidences as the palaeographical characteristics of text ${ }^{(12)}$, the formula ${ }^{(13)}$, the mentioning of the well known taxpayer.

From all the preceding evidences one can conclude that the text is Roman in date and referred to the reign of Augustus.

Ost. Nr. 1 (Pl. I)

25| 1

Inv.Nr./TR.18952/55/3, M.H.2881. Potsherd, brown.6x11 cm., thick., 0.4-0.5 cm. Roman (Augustus (21 January 6 B.C)).

Description: The text is complete. The ink is partly faint. The text is in a fair state of preservation. The handwriting is thick, rounded and compact. The handwriting of the first line is bigger than the rest of the lines.

\section{Transliteration:}

1) r.tw Hr-s3-Is.t s3 Pa-Mnt [ s3 ] Hr r

2) $p 3 \operatorname{shn} n n 3^{`} \cdot$ wj.w mht.w

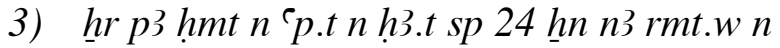

4) P3-wrm $s 3 \mathrm{Wn-nfr}$ sttr $2 . t r$ sttr $1 . t$

5) $r \operatorname{sttr} 2 . t^{\top} n$

6) $s \underline{h} n$ ḥ̉.t sp 24 tpj pr.t sw 26

\section{Translation:}

1) What $H \mathrm{r}-s 3-I s . t$ son of $\mathrm{Pa}-\mathrm{Mnt} \underline{\underline{t}}$ [son of ] $\mathrm{Hr}$ has paid to

2) the bank of the northern quarters

3) for the copper of poll (tax) in year 24 , among the men of

4) P3-wrm son of Wn-nfr, 2 staters makes 1 stater

5) Makes 2 staters again.

6) Written in year 24, tybi, day 26

(10) Mattha, op. cit., p. 45f.

(11) Wallace, op. cit., p. 134.

(12) El-Aguizy, O., A Palaeographical study of Demotic Papyri in the Cairo Museum from the Region of King Taharka to the End of the Ptolemaic Period (684-30 B.C.), Le Caire, 1998 (Mémoires publiés par les members de l'Institut Francais d'Archéologie Orientale du Caire, 113).

(13) Mattha, op. cit., p. 14ff. 
Notes:

$H \mathrm{r}-s_{3}-I s . t$ son of Pa-Mnt son of $H \mathrm{r}$ has paid 2 staters as an installment for the poll tax in year 24 at the bank of the northern quarters ${ }^{(14)}$.

- The taxpayer $H \mathrm{r}-s^{3}-{ }^{3} I s . t$ son of $\mathrm{Pa}-\mathrm{Mnt}$ son of $\mathrm{Hr}$ is mentioned before in a receipt of wheat, referred to 17 payni of year 4 of Tiberius, which equals to 11 June 8 A.D ${ }^{(15)}$.

\section{Sara Nabil Hafiz}

(14) This bank was located at the west bank of the nile at Jeme (Memnonia), see:Bogaert, "La Banque des Memnonia”, in: ZPE 86 (1991), pp. 259-263 see also: Mattha, op. cit. , nr. 1, n. L. 2; Wångsledt, S. P., Ausgewählte Demotische Ostraka aus der Sammlung des Victoria- Museum zu Uppsala und der Staatlichen Papyrussammlung zu Berlin, Uppsala, 1954, nr. 4, L. 1; Lichtheim,op.cit., nr. 25, n. 1; Nur El-Din, op. cit., nr. 58, n. L. 1.

(15) Lichtheim, op. cit., nr. 79, L. 1. 
Plate I
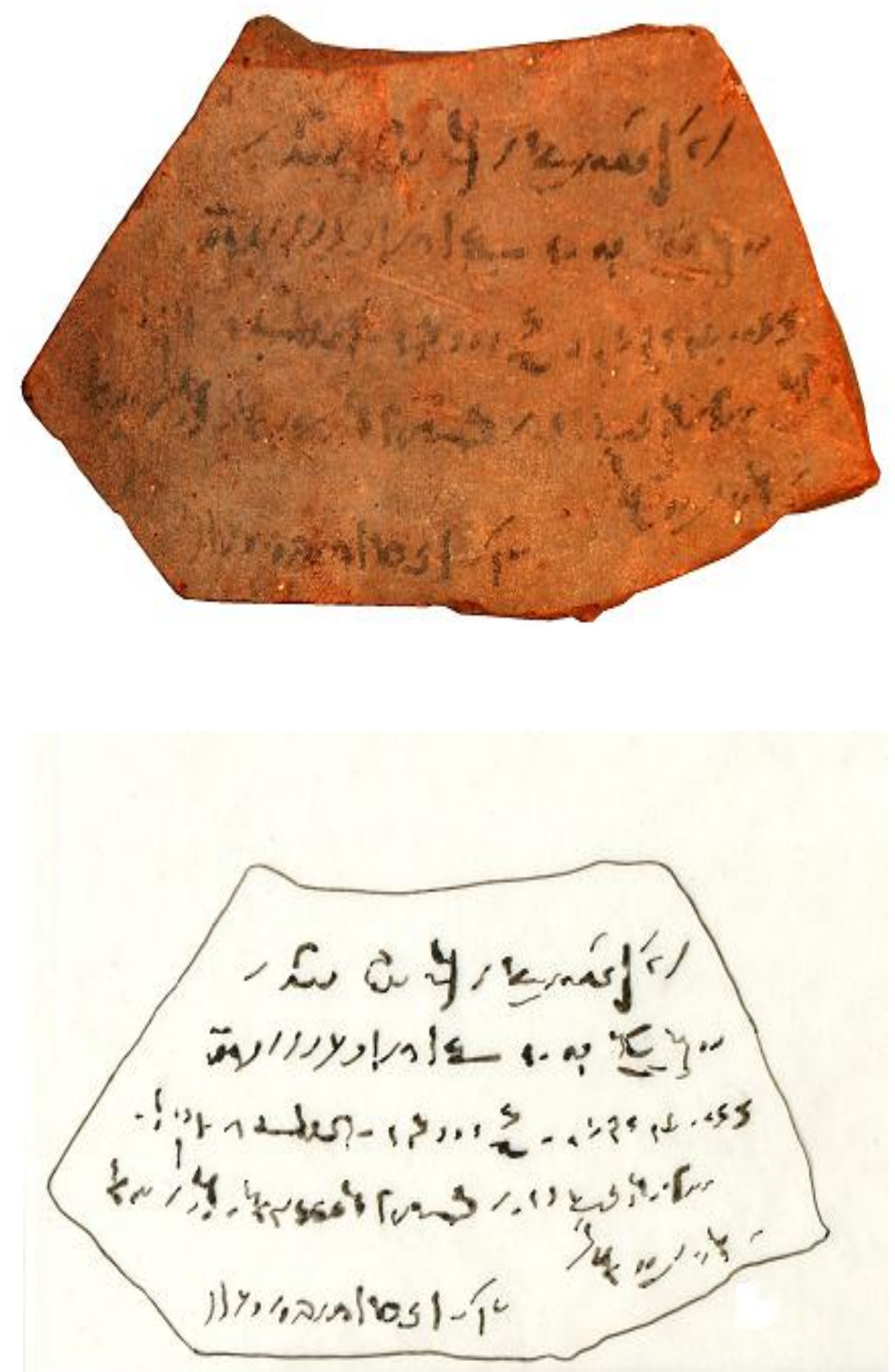

Ost. Nr.1 